EESTI NSV TEADUSTE AKADEEMIA TOIMETISED. XVII KOIDE

KEEMIA * GEOLOOGIA. 1968, Nr. 4

ИЗВЕСТИЯ АКАДЕМИИ НАУК ЭСТОНСКОИ ССР. ТОМ ХVII

ХИМИЯ * ГЕОЛОГИЯ. 1968, № 4

D. KALJO, V. VIIRA

NOTE ON THE AGE OF THE OHESAARE STAGE OF ESTONIA

\author{
A reply to L. E. Fåhraeus \\ D. KALJO, V. VIIRA. OHESAARE LADEME VANUSEST \\ Vastus L. E. Fåhraensele \\ Д. КАЛЬО, В. ВИНРА, О ВОЗРАСТЕ ОХЕСААРЕСКОГО ГОРИЗОНТА. \\ Ответ Л. Э. Фораузу
}

L. E. Fåhraeus, in Ludlow Research Group Bulletin No. 15, Feb. 1968, considers at least a part of the Ohesaare Stage as Gedinnian, defining in this stage the following conodonts: Spathognathodus cf. frankenwaldensis, $S$. steinhornensis remscheidensis, and S. steinhornensis ssp. indet.

We cannot agree with Fåhraeus's conclusion and, on the contrary, we must point out that the Ohesaare Stage seems to be not younger than the eosteinhornensis zone. As a proof to this assertion we consider the fact that the Ohesaare Stage on Ohesaare Cliff and the underlying beds of Kaugatuma Stage (at a depth of up to $45 \mathrm{~m}$ in the Ohesaare borehole) contain an abundant association of such conodonts as Lonchodina afí. detorta Walliser, Spathognathodus steinhornensis eosteinhornensis Walliser, S. primus (Branson \& Mehl), Ligonodina elegans Walliser, Neoprioniodina cf. bicurvata Branson \& Mehl, Plectospathodus flexuosus Branson \& Mehl, Ozarkodina ortuformis Walliser, O. typica Branson \& Mehl, Trichonodella $\mathrm{cf}$. inconstans Walliser.

Though we know that the subspecies of S. steinhornensis are difficult to define exactly, in the present case we are aided by the circumstance that the form occurring in the Ohesaare and Kaugatuma Stages is the earliest subspecies, since no representatives of S. steinhornensis could be found in the older beds of the Estonian sequence. Some morphological characters also speak in favour of $S$. s. eosteinhornensis.

Furthermore, the above-mentioned association also contains some species (Ligonodina elegans, Ozarkodina ortuformis) which do not occur higher thian the eosteinhornensis zone, whereas the typical representatives of the woschmidti association are entirely lacking.

Further proof against Fåhraeus's conclusion concerning the age of the Ohesaare Stage is the composition of the shelly fauna of Ohesaare and Kaugatuma Stages, and that of the ostracods in particular.

These data have already been commented upon with sufficient thoroughness (Кальо, Сарв, 1966; Martinsson, 1967), and we have only to add that new data obtained by J. Paškevičius from Lithuania and E. Witwicka (1967) from Poland show that the typical ostracods present in the Kaugatuma and Ohesaare Stages occur at the level of the Pristiograptus ultimus zone and immediately above the latter, in other words, lower than the Monograptus uniformis zone, which is considered as the beginning of the Gedinnian. 


\title{
REFERENCES
}

К а льо Д. Л., С а р в Л. И. 1966. К корреляции верхнесилурийских отложений Прибалтики, Изв. АН ЭССР, Сер. физ.-матем. и техн. наук, 15, № 2.

Martins s on A. 1967. The succession and correlation of Ostracode faunas in the Silurian of Gotland. Geol. Fören. Stockh. Förh., 89, pt. 2.

W it w i cka E. 1967. Ostracods of the Upper Silurian in Poland. Kwart. Geol., 1, No. I.

Academy of Sciences of the Estonian SSR. Institute of Geology
Received

May 31, 1968

EESTI NSV TEADUSTE AKADEEMIA TOIMETISED. XVII KÖIDE KEEMIA * GEOLOOGIA, 1968, $\mathrm{Nr} .4$

ИЗВЕСТИЯ АКАДЕМИИ НАУК ЭСТОНСКОЙ ССР. ТОМ ХVII

Химия * ГЕОЛогия. 1968, № 4

С. ИЫГИ, Х. СТУМБУР

\section{О ЗАВИСИМОСТИ РАСПРОСТРАНЕНИЯ ФОСФОРИТОВ ПАКЕРОРТСКОГО ГОРИЗОНТА ОТ ФАЦИАЛЬНОГО ТИПА ОКРУЖАЮЩИХ ОТЛОЖЕНИИ}

\author{
S. JOGI, H. STUMBUR. PAKERORDI LADEME FOSFORIITIDE LEVIKU SOLTUVUS OMBRITSE. \\ VATE SETETE FATSIAALSEST TUUBIST \\ S. JOGI, H. STUMBUR. DEPENDENCE OF THE DISTRIBUTION OF PHOSPHORITES OF THE \\ PAKERORT STAGE FROM THE FACIAL TYPES OF DEPOSITS ENCLOSING THEM
}

Для выявления распространения литофаций пакерортского горнзонта были использованы все доступные авторам геологические материалы, несмотря на их неоднородность в территориальном и качественном отношении.

В развитии Балтийского бассейна в пакерортское время выделяются два этапа. Образование осадков в раннепакерортское время в пределах территории Эстонии происходило в сложных палеотектонических условиях, при этом существенную роль играли, видимо, блоковые движения. В позднепакерортское время условия осадконакопления в Балтийском бассейне на территории Северной Әстонии выровнялись, и в это время отлагались в основном темно-коричневые илы с органическим вешеством и алевриты с прослоями и линзами ила.

В раннепакерортское время на фоне общих мелковсдных условий осадконакопления в бассейне выделялись некоторые более глубоководные участки. Мелководные условия преобладали местами в северо-восточной части, на юге в районе Мынистеского поднятия (где, по-видимому, осадконакопление временами даже прекращалось), а также в средней и западной частях Эстонии (см. рисунок). В этих районах отлагались маломощные (до 5 м) от средне- до разнозернистых, редко до крупнозернистых пески суурйыэской пачки с незначительным содержанием детрита раковин оболид и крупных галек.

Названные мелководные районы были отделены друг от друга более глубоководными участками бассейна, в осевых частях которых отлагались в основном алевриты юльгазеской пачки мощностью до 36 м.

В переходных между ними зонах отлагались мелкозернистые пески суурйыэской и маардуской пачек с большим содержанием детрита 